\title{
Analisis Struktur Anatomi Batang Anyelir (Dianthus caryophyllus L.) dan Kontribusinya terhadap Sistematik Ordo Caryophyllales
}

Emilia Juliyanti Bria ${ }^{\mathrm{a}}$

${ }^{a}$ Program Studi Biologi, Universitas Timor, Kefamenanu, TTU - NTT, Indonesia.

\section{Article Info}

Article history:

Received 8 April 2018

Received in revised form 19 Juni 2018

Accepted 5 Juli 2018

https://doi.org/10.32938/slk.vli1.413

Keywords:

Anatomi, Batang, Anyelir, Sistematika

\begin{abstract}
Abstrak
Caryophyllales dikenal sebagai ordo yang memiliki pertumbuhan sekunder anomaly. Anatomi batang Anyelir (Dianthus caryophyllus L.) dianalisis untuk mendapatkan data yang valid pada hubungan kekerabatan dengan angoota family yang lain. Struktur primer batangnya terdiri dari epidermis yang tersusun dari selapis sel; korteks dan empulur tersusun dari sel-sel parenkim dan memiliki ruang antarsel; dan jaringan pembuluh primer yang tersusun membentuk jari - jari terdiri atas beberapa trachea xilem, dimana xilem terletak di bagian dalam dan floem di bagian luar. Selanjutnya, pada pertumbuhan sekunder, batangnya memiliki struktur yang normal dengan aktivitas kambium yang tidak normal. Hal ini termasuk dalam ciri tumbuhan yang memiliki pertumbuhan sekunder anomali. Hasil penelitian ini dapa dijadikan karakter pembatas untuk memperkuat hubungan kekerabatan antar takson khususnya pada kategori yang lebih tinggi.
\end{abstract}

\section{Pendahuluan}

Anyelir (Dianthus caryophyllus L.) merupakan salah satu anggota bangsa Caryophylalles dari suku Caryophyllaceae yang menempati peringkat teratas perdagangan bunga potong di dunia. Anggota bangsa Caryophylalles, memiliki kesamaan ciri-ciri morfologi yaitu umumnya berupa terna. Daun tunggal, biasanya tanpa daun penumpu. Bunga banci atau tunggal, aktinomorf, dengan tenda bunga yang rangkap atau tunggal, atau jelas dengan kelopak dan mahkota. Benang sari dalam 1 lingkaran, berhadapan dengan tenda bunga atau dalam 2 lingkaran. Bakal buah tenggelam atau menumpang, kebanyakan beruang 1 dengan banyak sampai 1 bakal biji yang kampilotrop, yang hampir selalu mempunyai 2 selaput biji, terletak pada tembuni yang sentral (Tjitrosoepomo, 1982; Singh $d k k ., 2013$ ).

Selain memiliki kesamaran ciri morfologi, ditemukan juga kesamaan ciri anatomi dari beberapa Famili. Dalam penelitian Dima (2010) diketahui bahwa akar Amaranthus sp. (Famili Amaranthaceae) memiliki struktur anomali yang sama dengan batangnya, dimana floem primer tetap menempati posisi semula dan kambium pembuluh terletak di luar berkas pembuluh primer sehingga dihasilkan jaringan konjungtif dengan sejumlah lingkaran berkas pembuluh sekunder terbenam di dalamya. Selain itu, dalam penelitian Tododjahi (2010) diketahui juga bahwa akar Bougainvillea spectabilis (Famili Nyctaginaceae) juga mempunyai struktur sekunder menyimpang (anomali) yang sama dengan batangnya yaitu tidak memiliki kambium pembuluh normal tetapi hanya memiliki jaringan meristematis yang tersusun konsentris membentuk sejumlah lingkaran pertumbuhan.

Kajian anatomi perbandingan merupakan salah satu bukti yang sangat berperan penting dalam taksonomi. Kajian anatomi menyediakan bukti mengenai hubungan antar kelompok yang lebih besar seperti suku dan juga membantu membangun kedekatan nyata status taksonomi yang tidak pasti. Kombinasi karakter lebih dapat diandalkan daripada hanya terbatas pada satu karakter. Karakter anatomi baik organ vegetatif maupun organ generatif memiliki sifat lebih tetap dan plastisitas minimal. Karakter ini sampai sekarang merupakan karakter yang sukses dalam menyelesaikan permasalahan taksonomi takson takson khususnya kategori yang besar (Sharifnia \& Albouyeh, 2002; Faria $d k k$., 2012). Penelitian ini bertujuan untuk mendapatkan gambaran struktur anatomi batang anyelir dan untuk mengetahui susunan anatomis batang anyelir.

\section{Metode}

Penelitian ini merupakan penelitian eksploratif dengan metode deskriptif. Dilaksanakan pada bulan Oktober sampai dengan November tahun 2012 di Laboratorium Bioteknologi Politani Negeri Kupang. Pengumpulan data berupa gambar struktur anatomi hasil pengamatan mikroskop dan kemudian data gambar dianalisis lalu dibandingkan dengan teori dari referensi yang ada.

\section{Hasil dan Pembahasan}

\subsection{Struktur primer batang anyelir}

Struktur primer batang Anyelir dapat diketahui dengan melihat irisan melintang batang muda Anyelir (Gambar 1.). Pada penampang melintang batang, dilihat secara terpisah tiga sistem jaringan pada daerah pertumbuhan primer yaitu system jaringan dermal diwakili oleh epidermis; sistem jaringan dasar terdiri atas korteks dan empulur; dan sistem jaringan pengangkut yang terdiri dari xilem dan floem.

Sistem jaringan dermal pada batang Anyelir berupa epidermis yang menyelubungi tubuh primer dan terletak di bagian terluar batang (Gambar 1.B). Sel - sel epidermis tersusun atas satu lapis sel, rapat, tidak bercelah dan pada dinding yang menghadap ke atmosfer, didapatkan penebalan yang mengandung kutin. Epidermis batang Anyelir juga memiliki mulut daun atau stoma (jamak stomata) yang banyak. Berdasarkan tipe stomanya, stoma pada Anyelir memiliki tipe diasitik dimana setiap stoma dikelilingi oleh dua sel tetangga yang memotong stoma.

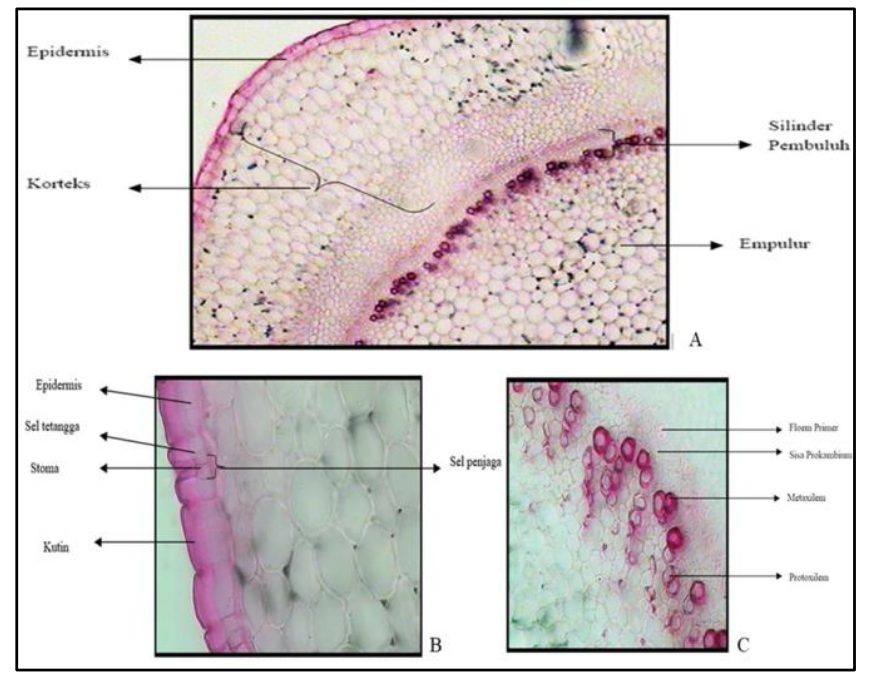

Gambar 1. Foto mikrograf irisan melintang batang anyelir: (A) struktur primer perbesaran 40x; (B) daerah epidermis perbesaran 400x; (C) jaringan pembuluh primer perbesaran $100 x$.

Daerah korteks ini tersusun atas sel-sel parenkim dan terdapat kloroplas. Di antara sel-sel tersebut terdapat ruang antar sel. Berdasarkan ukuran selnya, parenkim penyusun korteks pada batang Anyelir dibedakan atas dua bagian, dimana bagian yang pertama berbatasan dengan epidermis, terdiri atas sel-sel parenkim yang berukuran besar dan terdapat kloroplas yang memberi warna hijau pada daerah ini, sedangkan bagian yang dekat dengan silinder pusat memiliki ukuran yang lebih kecil. Selain itu, inti pusat jaringan dasar yaitu empulur juga tersusun atas sel-sel parenkim yang berukuran besar dan juga memiliki ruang antarsel (Gambar 1. A).

Sistem jaringan pembuluh primer merupakan hasil diferensiasi prokambium dan terletak pada bagian dalam korteks. Jaringan pembuluh ini, tersusun atas xilem dan floem yang dapat dilihat pada irisan melintang batang Anyelir (Gambar 1.C). Struktur jaringan pembuluh pada batang Anyelir berbeda dengan batang dikotil pada umumnya. Jaringan pembuluh pada batang Anyelir, tidak membentuk berkas-berkas tetapi xilem yang terletak di bagian dalam sisa prokambium, tersebar membentuk untaian seperti rantai ke arah empulur sedangkan floem membentuk struktur lingkaran di sebelah luar prokambium.

Xilem yang terbentuk pertama kali adalah protoxilem dan unsur xilem yang terbentuk kemudian adalah metaxilem yang menjadi dewasa secara sentrifugal, yang disebut xilem endark. Walaupun kedua macam xilem ini tidak dapat dibedakan dengan jelas dalam irisan melintang, namun diantara dua macam jaringan ini terdapat perbedaan struktural dimana protoxilem berukuran kecil dan metaxilem berukuran lebih besar. Sebagaimana pada xilem primer, dalam floem primer terdapat protofloem dan metafloem. Protofloem berdiferensiasi lebih dahulu daripada metafloem dan arah diferensiasinya secara sentripetal. Dari hasil penelitian sulit membedakan protofloem dan metafloem sehingga floem primer dianggap satu jaringan dan tidak ditentukan protofloem dan metafloemnya.

\subsection{Struktur sekunder batang anyelir}

Struktur sekunder batang Anyelir, memiliki struktur yang unik (Gambar 2.A). Pada tumbuhan yang mengalami pertumbuhan sekunder, periderm merupakan jaringan pelindung tubuh sekunder menggantikan fungsi epidermis. Namun hal ini tidak terjadi pada batang Anyelir. Pada irisan melintang batang tua Anyelir, ditemukan jaringan pelindungnya masih berupa epidermis yang tersusun atas selapis sel, dimana susunan sel - selnya rapat dan dinding sebelah luarnya terdapat penebalan berupa kutin (Gambar 2.B) 
Pada awal pertumbuhan sekunder batang Anyelir, terjadi proses sklerefikasi dimana adanya perubahan jaringan parenkim menjadi sklerenkim yang dimulai dari batas antara parenkim yang berukuran besar dan parenkim ukuran kecil (Gambar 2.B). Proses ini berlangsung terus - menerus sampai semua jaringan parenkim yang memiliki ukuran besar berubah menjadi sklerenkim. Jaringan sklerenkim yang terbentuk sebagai hasil sklerefikasi ini terdiri atas serabut. Serabut merupakan sklerenkim yang ukuran panjangnya jauh lebih besar dibandingkan lebarnya. Daerah korteks bagian dalam yang terdiri atas sel parenkim berukuran kecil, tidak menunjukkan adanya perubahan pada pertumbuhan sekunder. Pada bagian empulur, sel-sel penyusunnya masih berupa sel-sel parenkim yang memiliki ruang antar sel.

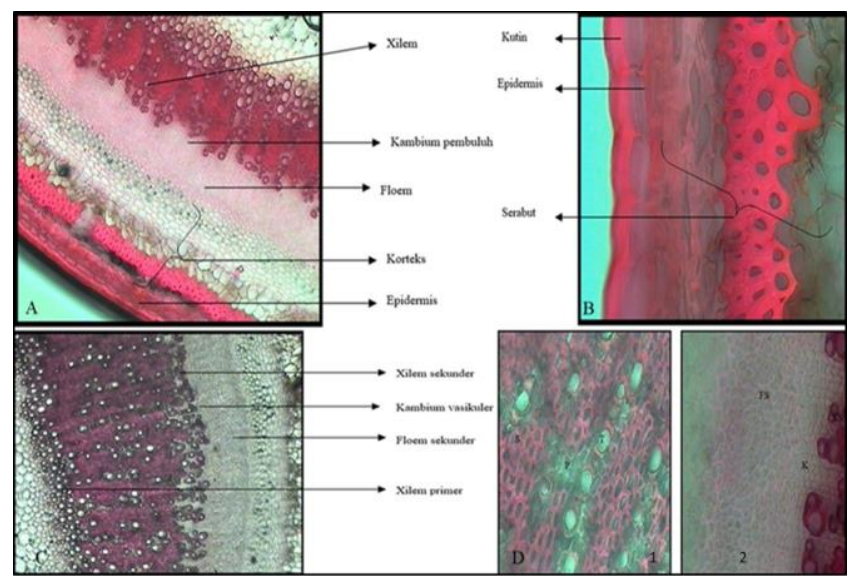

Gambar 2. Foto mikrograf irisan batang Anyelir : (A) pertumbuhan sekunder perbesaran 40x; (B) epidermis dan sebagian korteks perbesaran 400x; (C) jaringan pembuluh sekunder perbesaran 100x; (D) letak unsur pembuluh pada pertumbuhan sekunder 1). Susunan unsur xilem 2). Susunan unsur floem sekunder S: Serat Xilem, P: Parenkim Xilem T: Unsur Trakheari, XS: Xilem Sekunder, FS: Floem Sekunder, K: Kambium. Perbesaran 400x

Sistem jaringan pembuluh pada batang Anyelir berupa xilem sekunder dan floem sekunder yang merupakan hasil aktivitas kambium pembuluh. Posisi dan aktivitas kambium pada tanaman Anyelir adalah normal dimana menghasilkan ke arah dalam berupa xilem sekunder dan ke arah luar berupa floem sekunder, kambium ini disebut dengan kambium vasikuler. Selain itu, ada juga kambium intervasikuler yang berasal dari hasil dediferensiasi parenkim antar jari - jari pembuluh. Dari hasil penelitian, sulit menentukan kambium intervasikuler karena letak jari - jari xilem yang sangat rapat. Aktivitas kambium pembuluh yang menghasilkan xilem sekunder ke arah dalam, menyebabkan jari - jari xilem primer terdesak ke arah empulur yang terlihat tersebar tidak beraturan membentuk struktur bertumpuk. Struktur xilem sekunder yang dihasilkan oleh kambium juga tidak teratur. Carlquist (1995) menyatakan bahwa pada awal pertumbuhan sekunder anyelir, beberapa strip (1-2) sel - sel parenkim xilem sekunder mengalami pembelahan ke arah radial yang menyebabkan bagian ini bertambah lebar.

Diantara xilem primer dan xilem sekunder terdapat beberapa unsur xilem yang menghubungkan keduanya. Pada xilem sekunder, dapat dilihat komponenkomponen penyusunnya yakni unsur trakheari, parenkim xilem dan juga serat xilem (Gambar 2. D-1). Hal ini juga diungkapkan oleh Carlquist (1995), bahwa serat xilem menempati sebagian besar daerah batang pada pertumbuhan sekundernya. Floem sekunder memiliki komposisi, susunan, dan ukuran selnya beragam. Floem sekunder pada batang Anyelir yang dihasilkan ke arah luar oleh kambium pembuluh membentuk struktur melingkar seperti pada kambium pembuluh yang terdiri atas beberapa lapis sel (Gambar 2. D-2). Dalam penelitian ini tidak dapat diamati secara jelas, aktivitas kambium vaskulernya. Namun, Carlquist (1995) menyatakan bahwa aktivitas kambium anyelir sangat unik. Pada daerah perifer inti batang, kambium menghasilkan jaringan vaskular dalam orientasi terbalik; floem ke dalam dan xilem ke luar. Selain memproduksi floem, pada permukaan internalnya, kambium ini menghasilkan periderm internal ke floem.

Data - data di atas menunjukkan bahwa struktur primer dan struktur sekunder yang terbentuk pada batang Anyelir merupakan struktur anomaly yang memiliki aktivitas tidak normal dari kambium normal. Hal ini merupakan salah satu indikator batang berkayu pada suku Caryophyllaceae. Hasil penelitian ini dapat dijadikan salah satu karakter bernilai dalam menentukan hubungan kekerabatan pada kategori yang lebih besar.

\section{Simpulan}

Struktur primer batang Anyelir terdiri dari epidermis yang tersusun dari selapis sel; korteks dan empulur tersusun dari sel-sel parenkim dan memiliki ruang antarsel; dan jaringan pembuluh primer yang tersusun membentuk jari jari pendek, dimana xilem terletak di bagian dalam dan floem di bagian luar. Kemudian, pada pertumbuhan sekundernya menunjukkan struktur yang normal dan aktivitas kambium pembuluh yang anomali.

\section{Pustaka}

Carlquist, S. 1995. Wood Anatomy of Caryophyllaceae: Ecological, Habital. Systematic, And Phylogenetic Implications . Aliso, 14(1), 1 - 17

Dima, S. R. 2010. Analisis Struktur Anatomi Akar Tanaman Bayam (Amaranthus sp.). Skripsi. Universitas Nusa Cendana. Kupang. Tidak Dipublikasikan.

Faria, A.P.G. de, Vieira, A.C.M. \& Wendt, T. 2012. Leaf anatomy and its contribution to the systematics of Aechmea subgenus Macrochordion (de Vriese) Baker (Bromeliaceae). Anais da Academia Brasileira de Ciências, 84(4): 961-971.

Sharifnia, F., \& Albouyeh, R.M. 2002. Anatomical Studies in Relation to Taxonomy of Persian Linum Species. Pakistan Journal of Biological Sciences, 5 (11): 1240 - 1245

Singh, A.K., Singh, D.K., Singh, B., Punetha, S. \& Rai, D. 2013. Evaluation of carnation (Dianthus caryophyllus L.) varieties under naturally ventilated greenhouse in mid hills of Kumaon Himalaya. African Journal of Agricultural Research, 8(29): 4111-4114

Tododjahi, L.R. 2010. Analisis Struktur Anatomi Akar Tumbuhan Bogenvil (Bougainvillea spectabilis Willd). Skripsi. Universitas Nusa Cendana. Kupang. Tidak Dipublikasikan

Tjitrosoepomo, G. 1982. Taksonomi Tumbuhan Berbiji (Spermatophyta). Gadjah Mada University Press. Yogyakarta. 